\title{
Optimalisasi Kompetensi Moral Anak Usia Dini
}

\author{
Masganti Sit \\ Fakultas Tarbiyah IAIN Sumatera Utara \\ masganti@yahoo.com
}

\begin{abstract}
Abstrak: Tujuan penelitian ini adalah untuk mengoptimalkan kompetensi moral anak usia dini melalui pembelajaran terpadu berbasis moral. Penelitian dilakukan di Taman Kanak-kanak Tri Karya dan Taman Kanak-kanak Nusa Indah di Medan pada tahun 2008 dengan jumlah sampel sebanyak 35 orang anak. Penelitian tindakan ini menggunakan model dari Kemmis dan Taggart. Model ini telah dilaksanakan dalam dua siklus dan setiap siklus memiliki empat langkah yaitu: 1) perencanaan, 2) tindakan, 3) pengamatan, dan 4) refleksi. Analisis data menggunakan analisis kualitatif dan kuantitatif. Hasil analisis kualitatif menunjukkan bahwa pembelajaran terpadu berbasis moral melibatkan berbagai aktivitas, media, dan metode. Hasil analisis kuantitatif menunjukkan bahwa terdapat perbedaan yang berarti antara tes awal dan tes akhir kompetensi moral anak usia dini. Untuk menerapkan pembelajaran terpadu berbasis moral disarankan kepada guru, pengelola pendidikan anak usia dini, peneliti, dan pemerintah untuk merencanakan, melaksanakan, mengembangkan dan mendukung model pembelajaran terpadu berbasis moral.
\end{abstract}

Kata Kunci: Kompetensi Moral Anak Usia Dini, Pembelajaran Terpadu Berbasis Moral

\begin{abstract}
The objective of this research is to make early childhood's moral competence optimally through the integrated learning based-moral model. The study was conducted at Tri Karya and Nusa Indah Kindergartens in Medan in the year of 2008 with $n=35$. This action research was using Kemmis and Taggart model. The model has two cycles and each cycle has four steps. They are as follow (1) plan, (2) action, (3) observe and (4) reflect. To analyze the data, qualitative and quantitative were used. The result of the qualitative analyzes shows that the integrated learning based-moral model involved various activities, media and methods. The results of the quantitative analyze shows that there are significant differences between pre and post assessment of early childhood's moral competence. To applying the integrated learning based-moral model was suggested to teacher, manager of early childhood education institution, researcher, government to plan, act, develop, and promote integrated learning based-moral model.
\end{abstract}

Key Words: early childhood's moral competence, integrated learning based-moral model 


\section{Pendahuluan}

Pentingnya pendidikan moral atau akhlak dalam kehidupan manusia telah diperbincangkan dalam berbagai sudut pandang. Pendidikan akhlak dalam Islam dapat dipahami dari ayat al-Qur'an surat al-Qalam ayat 4 yang artinya: "Dan Sesungguhnya kamu benar-benar berbudi pekerti yang agung." Hadis Rasulullah saw juga menyatakan: "Sesungguhnya aku diutus untuk menyempurnakan akhlak yang mulia." (H.R. Baihaqi). Ayat alQur'an dan hadis Nabi ini menunjukkan bahwa pendidikan merupakan yang penting untuk menyelamatkan kehidupan dunia dan akhirat.

Kajian filosfis tentang pendidikan juga telah memunculkan berbagai rumusan tujuan pendidikan yang menyatakan bahwa pendidikan merupakan sarana menyempurnakan perkembangan potensi-potensi manusia termasuk perkembangan moral manusia. (Ornstein dan Levina, 1985: 76). Rumusan tujuan pendidikan ini menunjukkan bahwa pendidikan merupakan aspek penting dalam kehidupan manusia sekaligus menjadi hak setiap manusia sepanjang hayat.

Berbagai kebijakan yang memberikan kesempatan pendidikan pun dilahirkan mulai dari The World Education Forum pada Deklarasi Dakar di Senegal tahun 2000 yang menghasilkan komitmen tentang Pendidikan Untuk Semua (Education For $A l l$ ) sampai kepada komitmen pemerintah dengan ditetapkannya UndangUndang Republik Indonesia Nomor 23 Tahun 2002 tentang Perlindungan Anak dan Undang-Undang Republik Indonesia Nomor 20 Tahun 2003 tentang Sistem Pendidikan Nasional khususnya pasal 28 tentang pendidikan anak usia dini, serta terbentuknya Direktorat Pendidikan Anak Usia Dini.

Di sisi lain pada Pasal 3 Undang-Undang Republik Indonesia Nomor 20 Tahun 2003 dinyatakan bahwa tujuan pendidikan nasional pada semua jenjang dan jenis satuan pendidikan, termasuk pendidikan anak usia dini adalah berkembangnya potensi peserta didik agar menjadi manusia yang beriman dan bertakwa kepada Tuhan Yang Maha Esa, berakhlak mulia, sehat, berilmu, cakap, kreatif, mandiri, dan menjadi warga negara yang demokratis serta bertanggung jawab. Pernyataan ini menunjukkan bahwa menanamkan dan mengembangkan nilainilai moral pada peserta didik menjadi salah satu tujuan pendidikan nasional, bahkan aspek moral menjadi aspek yang penting dalam pendidikan. Namun berbagai kenyataan menunjukkan kompetensi siswa pada aspek moral masih memprihatinkan.

Kasus pelanggaran moral telah terjadi bahkan dari tingkat sekolah dasar. Seorang anak Sekolah Dasar Negeri 27 Pemecutan Denpasar pada tahun 2005 terlibat perkelahian hingga menewaskan temannya dan menyebabkannya dijatuhi hukuman 10 tahun penjara (http:// www.ypha.or.id). Bulan Januari tahun 2007 di Kediri, seorang siswa kelas VI SD menjadi tersangka tunggal kasus pembunuhan murid Taman Kanak-kanak dan menyebabkannya masuk Lapas Kediri (http://www.antara.com). Pada bulan Juni tahun 2006, di pasar Tabanan, Denpasar siswa Sekolah Dasar terlibat dalam kasus-kasus pencurian uang dari plangkiran (tempat ibadah Agama Hindu) dengan alasan untuk membayar uang sekolah (Tempo, 13 Juni 2006).

Kasus-kasus di atas memang tidak terjadi pada murid Taman Kanak-kanak namun bukan tidak mungkin kebiasaan-kebiasaan kurang patuh terhadap aturan dan kurang bertanggung jawab telah tersemai sejak usia dini. Bernt (1997:64) menyatakan salah satu persyaratan untuk patuh terhadap aturan dalam setiap situasi adalah kontrol diri. Kontrol diri telah muncul pada usia prasekolah. Kontrol diri merupakan persyaratan yang paling penting dalam perilaku moral. Oleh sebab itu, Locke (dalam Deighton, 1967:489) menyatakan anak-anak harus diajarkan untuk patuh terhadap moral sejak usia dini.

Dryden (dalam Rakhmawati, 2002) juga menyatakan pentingnya mengajarkan moral sejak usia dini sebab lima puluh persen kemampuan belajar seseorang dikembangkan pada empat tahun pertamanya. Kohlberg (1976:115) menyatakan diskusi dilema moral dapat mengembangkan pemikiran moral anak. Berk (2006:480) menyatakan perilaku moral diperoleh dengan cara yang sama dengan respon-respon lainnya, yaitu melalui modeling dan penguatan. Lewat pembelajaran modeling pada anak usia dini akan terjadi internalisasi berbagai perilaku moral, prososial dan aturan-aturan lainnya untuk tindakan yang baik. 
Di sisi lain Martini Jamaris (2005:76) menyatakan bahwa Pembelajaran terpadu bertujuan membantu anak usia dini mengaktualisasikan berbagai potensinya ke dalam berbagai bentuk kemampuan fisik (motorik kasar dan halus, intelegensi, emosi, spritual, sosial, agama, moral, bahasa, dan komunikasi). Pembelajaran terpadu berbasis moral adalah pembelajaran yang memasukkan nilai-nilai moral secara terencana ke dalam tema dan setiap kegiatan pembelajaran.

Rumusan masalah penelitian ini yaitu: a) Bagaimanakah tingkat kompetensi moral siswa Taman Kanak-kanak B sebelum dilakukan intervensi tindakan pembelajaran terpadu berbasis moral? b) Bagaimanakah optimalisasi kompetensi moral siswa Taman Kanak-kanak B dengan menggunakan pembelajaran terpadu berbasis moral? c) Apakah kompetensi moral siswa Taman Kanak-kanak B dapat dioptimalkan setelah melakukan pembelajaran terpadu berbasis moral?

Penelitian ini bertujuan untuk mengetahui: a) tingkat kompetensi moral anak usia dini sebelum pembelajaran terpadu berbasis moral, b) cara mengoptimalkan kompetensi moral anak usia dengan menggunakan pembelajaran terpadu berbasis moral, dan c) keberhasilan pembelajaran terpadu mengoptimalkan kompetensi moral anak usia dini.

\section{Kajian Literatur \\ Kompetensi Moral}

Schulheiss dan Brunstein (2005: 42) menyatakan kompetensi adalah keterampilan dan kemampuan seseorang yang telah dikembangkan. Keterampilan dan kemampuan tersebut menyebabkan seseorang dapat melakukan transaksi yang efektif dengan lingkungan dan sukses melaksanakannya. Weiner (2005: 79) mengartikan kompetensi sebagai kemampuan untuk menyelesaikan suatu tugas yang mungkin dapat dicapai karena ketangkasan. Landy dan Conte sebagaimana dikutip Kanfer dan Ackerman (2005: 459) mendefinisikan kompetensi sebagai satu set perilaku yang biasanya dipelajari lewat pengalaman yang merupakan instrumen untuk pencapaian berbagai aktivitas yang merujuk kepada integrasi sifat-sifat individual yang beragam untuk tujuan-tujuan yang bersifat khusus.
Moral berasal dari kata Mores atau mos yang berarti kesusilaan, tabiat, atau kelakuan. Sjarkawi (2006:34) menyatakan moral adalah nilai kebaikan manusia sebagai manusia. Henderson (1964:112) menyatakan moralitas menunjukkan perbuatan terhadap diri sendiri atau orang lain yang diperlukan untuk mencapai tujuan akhir manusia yaitu kehidupan yang baik. Haris (1976:31) menyatakan moralitas adalah wilayah dari perilaku yang berkaitan dengan hal-hal yang benar dan salah, baik dan buruk, dan tentang tugas dan kewajiban. Durkheim (1990:5) menyatakan bahwa moralitas akan mencegah individu agar tidak melakukan hal-hal yang terlarang.

Kata moral selalu dipandang memiliki makna yang tumpang tindih dengan kata akhlak, etika, budi pekerti, dan nilai. Namun pada hakekatnya ada beberapa perbedaan di antara kelima istilah ini. Akhlak menekankan perbuatan baik yang dilakukan dalam berhubungan dengan Allah, manusia, dan alam untuk mencari keridhaan Allah. Etika adalah bagian dari filsafat yang membicarakan perbuatan baik dan buruk. Budi pekerti adalah kumpulan tata krama yang dipandang baik dalam budaya tertentu. Nilai merupakan rujukan dalam menentukan keputusan dalam melakukan suatu perbuatan. Moral adalah perbuatan baik yang mensejahterakan kehidupan manusia. Persamaan kelima istilah terletak pada inti pembicaraannya tentang perbuatan terpuji yang seharusnya dilakukan manusia untuk mencapai kehidupan yang lebih baik.

Lind (www.uni-konstanz.de) mendefenisikan kompetensi moral sebagai kesadaran terhadap satu perilaku moral yang universal (aspek afektif) dan kemampuan untuk mengaplikasikan prinsipprinsip perilaku moral secara konsisten. Catalano dkk (1998:5) mendefenisikan kompetensi moral sebagai kemampuan untuk menilai dan merespon sebuah situasi berdasarkan dimensi etika, afektif, atau keadilan sosial. Kohlberg (www.unikonstanz.de) mendefenisikan kompetensi pertimbangan moral sebagai kemampuan untuk keputusan dan pertimbangan moral dan bertindak sesuai dengan pertimbangan tersebut. Winston (2002:1) mendefenisikan kompetensi moral sebagai satu set sifat dan watak yang membuat perilaku yang baik. Lickona (1991: 61- 
62) menjelaskan kompetensi moral merupakan bagian dari tindakan moral. Di dalam penelitian kompetensi moral anak usia didefenisikan sebagai kemampuan yang meliputi pengetahuan moral, perasaan moral, dan tindakan moral yang disesuaikan dengan tahap perkembangan moral anak.

\section{Pembelajaran Terpadu Berbasis Moral}

Asri C. Budiningsih (2004:2) dengan mengutip Paul Suparno menyatakan ada empat model penyampaian pembelajaran moral, yaitu: 1) model sebagai mata pelajaran tersendiri, 2) model terintegrasi dalam semua bidang studi, 3 ) model di luar pengajaran, dan 4) model gabungan.

Martin dan Reigeluth (1999: 493-499) menyatakan ada tujuh isu yang berkaitan dengan desain pengembangan kurikulum afektif. Salah satu isu tersebut adalah kurikulum terpadu yang merujuk kepada bagaimana topik-topik atau program-program afektif diintegrasikan ke dalam subjek-subjek dalam kurikulum. Program-program afektif mengalir di dalam kurikulum tersebut. Salah satu program afektif tersebut adalah memasukkan nilai-nilai moral ke dalam kurikulum terpadu. Wilson (dalam Sharma, 2006: 225) mengatakan bahwa pembelajaran yang cocok untuk pembelajaran moral adalah metode pembelajaran langsung, di antara metode yang dapat dipergunakan adalah drama, diskusi, dan bermain peran.

Lickona (1991: 166) menyatakan sekolahsekolah di Maine, pada awal tahun 1980-an telah meluncurkan sebuah program pendidikan yang berpusat pada enam nilai yang tidak memiliki kontroversi yaitu: respek, keberanian, kejujuran, keadilan, kesediaan untuk bekerja, dan disiplin diri. Setiap sekolah dituntut untuk memasukkan nilai-nilai tersebut ke dalam seluruh kurikulum dan kegiatan harian sekolah. Lebih dari itu dituntut pula selama satu tahun ajaran satu dari enam nilai tersebut harus menjadi "Nilai satu Tahun." Misalnya, selama "Tahun Nilai Disiplin Diri" pimpinan sekolah harus memberikan saran-saran yang relevan kepada para guru untuk memasukkan nilai-nilai tersebut kedalam semua mata pelajaran: misalnya guru sejarah dapat menggambarkan model disiplin diri dari kajian literatur. Murid-murid dapat diminta menulis komposisi yang berkaitan dengan sifat-sifat yang paling penting dari karakter tersebut. Sementara guru seni dan musik dapat menguji kehidupan artis-artis dan komposerkomposer besar sebagai model dari disiplin diri. Di Inggris, Institute Josepshon, 1992 (dalam Berkowitz (http://tigger.uic.edu) menginformasikan bahwa telah memasukkan enam pilar karakter ke dalam perundang-undangan pendidikan. Keenam nilai tersebut adalah sifat dapat dipercaya, respek, bertanggung jawab, keadilan, kepedulian, dan kewarganegaraan.

Di Indonesia pendidikan terpadu berbasis karakter yang menggunakan pendekatan pembelajaran terpadu telah menjadikan nilai moral sebagai basis pembentukan karakter. Nilainilai moral yang digunakan disebut enam pilar nilai-nilai karakter. Model pembelajaran ini telah dikembangkan oleh Indonesia Heritage Foundation (IHF). Kurikulum ini telah mengintegrasikan sembilan nilai karakter yaitu: 1) Cinta Tuhan dan segenap ciptaan-Nya, 2) Kemandirian dan Tanggung Jawab, 3) Kejujuran/Amanah, Bijaksana, 4) Hormat dan Santun, 5) Dermawan, Suka Menolong dan Gotong Royong, 6) Percaya diri, Kreatif, dan Pekerja Keras, 7) Kepemimpinan dan Keadilan, 8) Baik dan Rendah Hati, 9) Toleransi, Kedamaian, dan Kesatuan. Sembilan pilar tersebut diintegrasikan ke dalam berbagai aspek pengembangan pada pembelajaran terpadu di taman kanak-kanak. (Ratna Megawangi, 2007:100).

Di dalam penelitian ini pembelajaran terpadu berbasis moral yang dilaksanakan memasukkan nilai disiplin, keadilan, menghormati orang lain, menolong orang lain, kebersihan, dan ke dalam tema dan kegiatan pembelajaran dengan menggunakan berbagai media dan metode. Tema yang dipilih tema yang paling dekat dengan nilainilai moral yang akan dioptimalkan.

\section{Perkembangan Moral Anak Usia Dini}

Ada tiga teori yang membicarakan perkembangan moral pada anak usia dini. Teori psikoanalisa yang digagas Sigmund Frued menyatakan bahwa perkembangan moral telah terjadi pada anak usia 3 dan 6 tahun. Frued (dalam Berk, 2006: 515) menyakini moralitas muncul sebagai resolusi dari konflik Oedipus dan Elektra selama tahun. Ketakutan hukuman dan kehilangan cinta 
orangtua mendorong anak untuk membentuk superego melalui identifikasi dengan orangtua yang berjenis kelamin sama dan untuk mengalihkan dorongan permusuhan kepada rasa bersalah dalam diri anak.

Teori kognitif diwakili Jean Piaget dan Lawrence Kohlberg menyatakan perkembangan moral pada anak telah terjadi sebelum usia 7 tahun. Piaget (1969: 124) berdasarkan observasi dan wawancaranya terhadap anak-anak usia 4 sampai 12 tahun tentang Piaget aturan-aturan etis, misalnya mencuri, berbohong, hukuman, dan keadilan menyatakan bahwa anak sebelum 7 atau 8 tahun berada pada tahap heteronomous morality. Pada tahap ini keadilan dan aturanaturan dibayangkan anak-anak sebagai sifat-sifat dunia yang tidak boleh berubah, yang lepas dari kendali manusia. Misalnya pada tahap ini anakanak akan mengatakan bahwa memecahkan dua gelas secara tidak sengaja lebih buruk daripada memecahkan satu gelas dengan sengaja ketika mencoba mencuri kue. Anak-anak belum memasukkan niat sebagai bagian untuk menilai sebuah perbuatan moral.

Kohlberg (1976:68) melalui tes (berbentuk pertanyaan-pertanyaan yang dikaitkan dengan serangkaian cerita dimana tokoh-tokohnya menghadapi dilema moral) yang dilakukannya kepada 75 orang anak laki-laki yang berusia antara 4 hingga 16 tahun menyatakan bahwa perkembangan moral anak-anak prasekolah atau pelajar sekolah dasar, berada tahap prakonvensional (preconventional). Ini adalah tingkat yang paling rendah dalam tahap perkembangan moral. Pada tingkat ini, anak memperlihatkan internalisasi nilai-nilai moral-penalaran moral dikendalikan oleh imbalan (hadiah) dan hukuman eksternal. Tingkat ini dibagi kepada dua tahap: tahap pertama, orientasi hukuman dan ketaatan, dan tahap kedua individualisme dan tujuan.

Teori belajar sosial belajar sosial diwakili Bandura (http://www.ship. edu/ cgboeree/ perscontents.html) memandang perilaku moral diperoleh dengan cara yang sama dengan responrespon lainnya, yaitu melalui modeling dan penguatan. Model-model yang efektif adalah sesuatu yang hangat, kuat dan pertunjukan yang konsisten antara apa yang dikatakan dan apa yang dilakukan. Lewat pembelajaran modeling anak-anak usia dini terjadi internalisasi berbagai perilaku prososial dan aturan-aturan lainnya untuk tindakan yang baik.

Menurut Santrock (1996: 271) teori belajar sosial menyatakan bahwa perkembangan moral dipengaruhi secara ekstensif oleh situasi. Pengaruh yang ekstensif ini diperoleh lewat proses penguatan, penghukuman, dan peniruan. Di samping itu, agar anak-anak dapat berperilaku sesuai dengan aturan moral kendali diri anak harus dikembangkan. Anak-anak harus belajar sabar menunda kenikmatan. Contoh latihan kesabaran dilakukan Mischel dan Pattersons pada tahun 1976 (dalam Santrock, 1996: 275) dalam sebuah investigasi. Dalam investigasi tersebut mereka meminta anak-anak prasekolah melakukan pekerjaan yang membosankan dan di dekatnya ada badut yang mengajaknya bermain. Anak-anak yang terlatih akan mengatakan: "Aku tidak akan melihat Pak Badut ketika Pak Badut memintaku melihatnya." Anak-anak yang terlatih lebih tahan lama mengerjakan pekerjaan yang membosankan tersebut daripada anak-anak yang tidak terlatih.

Nace Toner dan koleganya (dalam Shaffer, 2002: 529) menemukan anak usia 6-8 tahun yang dipersuasi dengan model yang mengajarkan moral lebih dapat mengendalikan diri dari godaan daripada anak-anak yang tidak memiliki model untuk ditiru. Implikasi dari penemuan ini menurutnya dapat membantu orangtua mengontrol perilaku-perilaku yang tidak diingini pada anak dengan menggunakan model-model yang dapat ditiru anak. Berdasarkan dari berbagai teori tentang perkembangan moral pada anak usia dini terlihat bahwa dengan perkembangan kognitif pada anak usia dini telah menjadikan mereka mampu membedakan perbuatan-perbuatan yang sesuai dengan aturan moral atau melanggar moral. Perkembangan perasaan moral anak menurut Frued telah menunjukkan bahwa anak usia menyukai melakukan perbuatan-perbuatan baik untuk mendapatkan kasih sayang orang tuanya. Di sisi lain, anak usia dini juga telah memiliki kemampuan meniru perilaku baik yang ditunjukkan oleh orang-orang di sekitarnya. Perkembangan pengetahuan, perasaan, dan peniruan tindakan moral ini memungkinkan anakanak usia dini mengembangkan kompetensi moralnya. 


\section{Kerangka Konseptual Perencanaan Tindakan}

Berdasarkan kajian teori dapat dikemukakan kerangkan konseptual penelitian sebagai berikut:

Pembelajaran Terpadu Berbasis Moral Nilai Moral: disiplin, keadilan, rasa

hormat, kepedulian terhadap orang lain, kebersihan, dan kejujuran

$\longrightarrow \begin{aligned} & \text { Kompetensi Moral Anak Usia Dini } \\ & \text { - Pengetahuan Moral } \\ & \text { - Perasaan Moral } \\ & \text { - Tindakan Moral }\end{aligned}$

Keterangan:

$\longrightarrow$ : Pembelajaran Terpadu Berbasis Moral mengoptimalkan Kompetensi moral Anak Usia Dini

: Jika optimalisasi kompetensi moral Anak Usia Dini belum mencapai target penelitian, Pembelajaran Terpadu Berbasis Moral harus disempurnakan dan diulang pelaksanaannya.

\section{Hipotesis Penelitian Tindakan}

Hipotesis penelitian ini adalah: "Pembelajaran Terpadu Berbasis Moral dapat mengoptimalkan kompetensi moral Anak Usia Dini."

\section{Metode Penelitian}

Tempat penelitian tindakan ini adalah Taman Kanak-kanak Trikarya, di Medan dan di Taman
Kanak-kanak Nusa Indah di Medan sebagai tempat uji efektivitas model pembelajaran terpadu berbasis moral setelah target penelitian telah tercapai dalam siklus-siklus. Penelitian dilaksanakan dari bulan Januari sampai bulan Juni tahun 2008.

Perencanan penelitian tindakan ini menggunakan prosedur kerja Kemis dan Taggart (1997: 11-14) dengan dua siklus. Langkah-langkah dalam tiap siklus meliputi: a) perencanaan (planning), b) tindakan (acting), c) observasi (observation), d) refleksi (reflection). Apabila siklus pertama belum tercapai akan dilanjutkan selanjutnya sehingga tercapai tujuan penelitian. Setelah target penelitian tercapai, siklus dapat dihentikan dan dilanjutkan dengan uji efektivitas dengan eksprimen sederhana. Desain pelaksanaan tindakan pembelajaran terpadu berbasis moral untuk meningkatkan kompetensi moral siswa Taman Kanak-kanak pada penelitian ini dapat digambarkan sebagai berikut:

Desain Penelitian Tindakan Optimalisasi Kompetensi Moral Anak Usia Dini

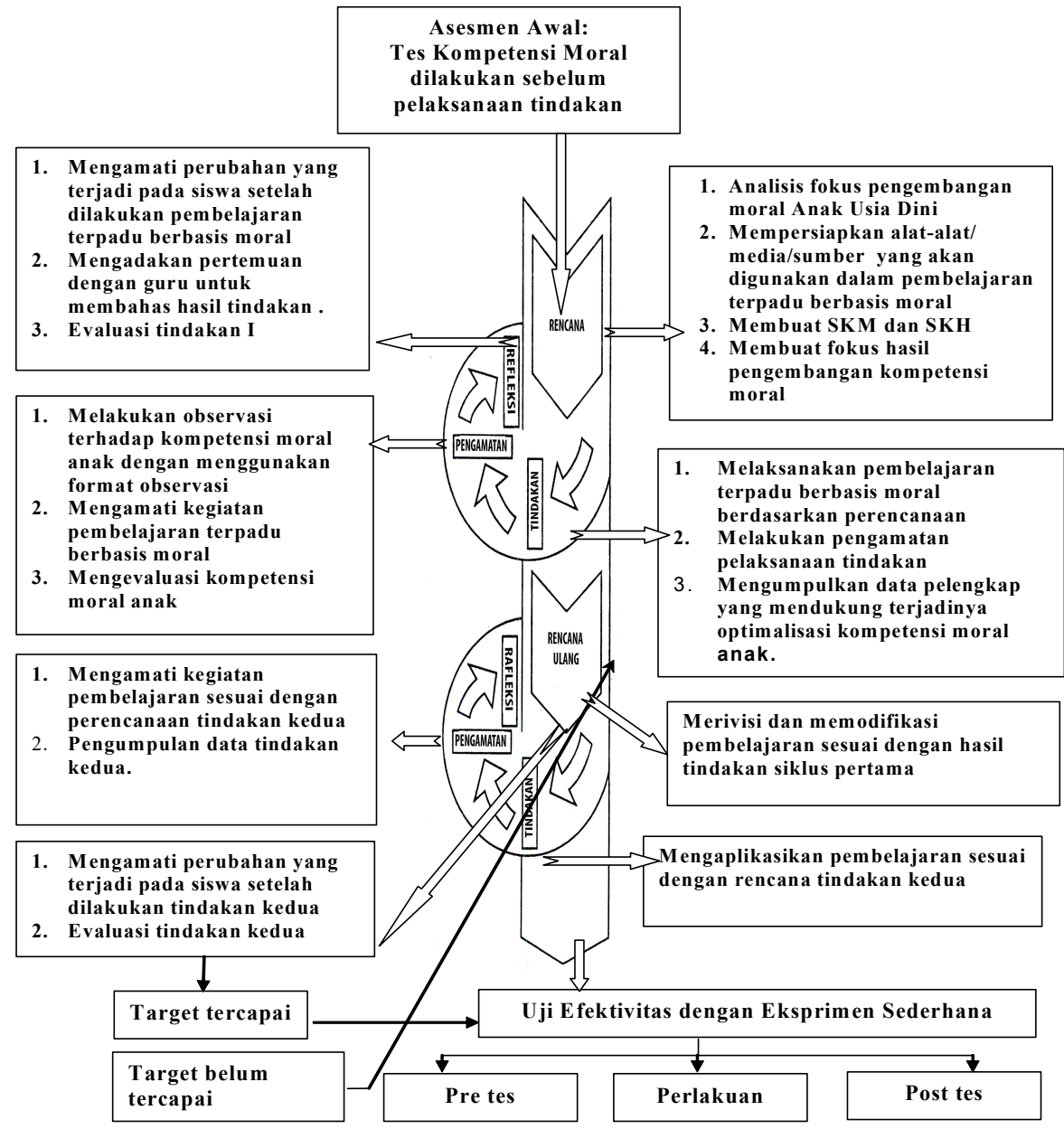


Instrumen yang digunakan untuk pengamatan tentang tindakan yang dilakukan dalam penelitian ini: a) lembar observasi dan catatan lapangan digunakan untuk mencatat hasil observasi pelaksanaan pembelajaran terpadu berbasis moral dan peningkatan kompetensi moral siswa selama pembelajaran berlangsung, b) fotofoto dan video untuk merekam kegiatan selama pembelajaran berlangsung, dan c) Asesmen digunakan pada saat asesmen awal dan asesmen akhir. Asesmen yang digunakan berbentuk: wawancara yang dilakukan dengan melakukan stimulasi verbal plus alat-alat peraga (gambar) dan lembar observasi tindakan moral anak.

Variabel penelitian ini adalah kompetensi moral anak usia dini yang diperoleh dari skor total kemampuan anak untuk menjawab pertanyaanpertanyaan yang berkaitan dengan pengetahuan moral dan perasaan moral, serta perilaku tindakan moral anak yang dikumpulkan dengan pengamatan. Dalam penelitian nilai moral yang harus dikuasai siswa pada ketiga dimensi kompetensi moral (pengetahuan moral, perasaan moral, dan tindakan moral) terbatas pada disiplin, keadilan, menghormati orang lain, kepedulian terhadap orang lain, kebersihan, dan kejujuran.

Target penelitian ini adalah optimalisasi kompetensi moral anak sebesar kategori B (75\% alat ukur yang digunakan). Penetapan target ini merujuk kriteria yang ditawarkan Mills (2003:100) yang memberi kriteria baik diberikan jika peserta didik dapat menjawab pertanyaan atau melakukan perbuatan yang harus dikuasainya dalam pembelajaran antara $60-75 \%$ dari alat ukur. Pada penelitian skor kompetensi moral yang harus dicapai anak adalah 208, dengan perincian skor 90 untuk dimensi pengetahuan moral, skor 68 untuk dimensi perasaan moral, dan skor 50 untuk dimensi tindakan moral.

Pemeriksaan keabsahan data pada penelitian menggunakan kriteria yang dikemukakan oleh Guba (1981) yang dikutip dari Mills, yaitu: derajat kepercayaan (Credibility), keteralihan (Transferability), ketergantungan (Dipendability) dan kepastian (Confirmability).

Analisis data dalam penelitian tindakan ini menggunakan analisis gabungan yaitu menggabungkan analisis kuantitatif dengan analisis kualitatif (mixed). Analisis kuantitatif meng- gunakan uji-t sampel berpasangan ( $t$-paired sample) dan uji t-sampel tunggal ( $t$-one sampel). Analisis kualitatif menggunakan teknik etnografi dari Spradley.

\section{Hasil Penelitian Dan Pembahasan}

\section{Deskripsi dan Analisis Data Kualitatif}

Pada siklus pertama dengan pembelajaran yang dilaksanakan selama dua minggu menggunakan tema "Alat Komunikasi." Kegiatan-kegiatan optimalisasi kompetensi moral mencakup kegiatan optimalisasi dimensi pengetahuan, perasaan, dan tindakan moral. Pada kegiatan optimalisasi dimensi pengetahuan moral digunakan media gambar dengan metode mengamati gambar, tanya jawab dan penugasan. Pada kegiatan optimalisasi perasaan digunakan media gambar dan metode tanya jawab dan bimbingan. Pada kegiatan optimalisasi tindakan moral digunakan metode bimbingan dengan nasehat dan penguatan.

Pada siklus kedua dengan pembelajaran dilaksanakan selama dua minggu pada menggunakan tema "Negaraku". Kegiatankegiatan optimalisasi kompetensi moral mencakup kegiatan optimalisasi dimensi pengetahuan, perasaan, dan tindakan moral. Pada kegiatan optimalisasi dimensi pengetahuan moral digunakan media gambar visual dan permainan moral dengan metode mengamati gambar visual, bermain peran, tanya jawab dan penugasan. Pada kegiatan optimalisasi perasaan digunakan media gambar visual dengan metode tanya jawab dan bimbingan. Pada kegiatan optimalisasi tindakan moral digunakan media permainanpermainan moral dengan metode bermain peran, praktek langsung dan metode bimbingan dengan nasehat dan penguatan.

\section{Deskripsi dan Analisis Data Kuantitatif}

Setelah selesai pembelajaran selama dua minggu dilakukan asesmen akhir siklus pertama dengan hasil perolehan perhitungan nilai rata-rata kompetensi moral anak sebesar 225, median 220 mode 232, dan standar deviasi sebesar 16.4. Jika dibandingkan dengan jumlah nilai tertinggi dari instrumen kompetensi moral dalam penelitian ini yaitu 276 maka nilai kompetensi moral yang dicapai anak pada siklus I berada pada kategori A (sangat baik). 
Capaian skor kompetensi moral anak sudah mencapai target penelitian yaitu kategori B (baik), namun jika dilihat nilai rata-rata dari tiap dimensi dari kompetensi moral yaitu pengetahuan moral, perasaan moral, dan tindakan moral diperoleh perhitungan pengetahuan moral nilai rata sebesar 103 (sangat baik), perasaan moral nilai rata 72,8 (baik), dan tindakan moral nilai rata 47 (baik). Disebabkan aspek tindakan moral belum mencapai target penelitian yaitu skor 50, maka penelitian dilanjutkan ke siklus kedua.

Setelah selesai pembelajaran selama dua minggu pada siklus kedua, hasil asesmen akhir menunjukkan nilai rata-rata kompetensi moral anak Taman Kanak-kanak Trikarya kelompok B $^{2}$ sebesar 257 (sangat baik). Capaian skor kompetensi moral anak untuk seluruh dimensi telah melebihi target penelitian. Nilai rata-rata aspek pengetahuan moral adalah 115 (Sangat Baik), nilai rata-rata aspek perasaan moral adalah 86 (Sangat Baik), dan nilai rata-rata aspek tindakan moral adalah 57 (Sangat Baik). Disebabkan semua aspek telah melebihi target capaian penelitian, maka siklus-siklus penelitian dapat dihentikan.

Grafik optimalisasi kompetensi moral dalam siklus 1 dan siklus 2 sebagai berikut:

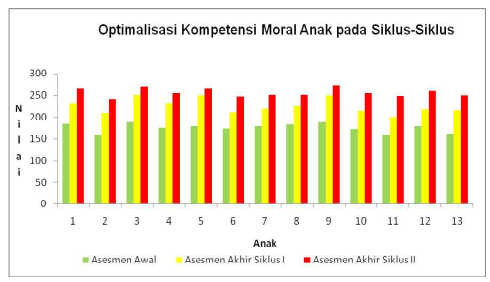

Grafik 1. Optimalisasi Kompetensi Anak Usia Dini Pada Siklus 1 dan Siklus 2

Grafik optimalisasi tiap dimensi pengetahuan moral dalam siklus 1 dan siklus 2 sebagai berikut:

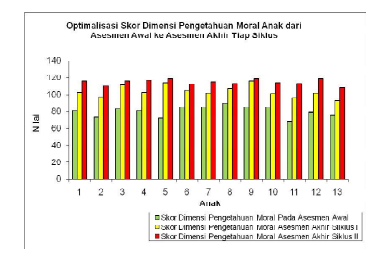

Grafik 2. Optimalisasi Dimensi Pengetahuan Moral Anak Pada Siklus 1 dan 2
Grafik optimalisasi dimensi perasaan moral pada siklus 1 dan siklus 2 sebagai berikut:

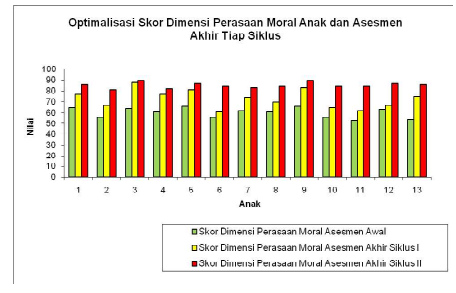

Grafik 3. Optimalisasi Dimensi Perasaan Moral Anak Pada Siklus 1 dan 2

Grafik optimalisasi dimensi tindakan moral pada siklus 1 dan siklus 2 sebagai berikut:

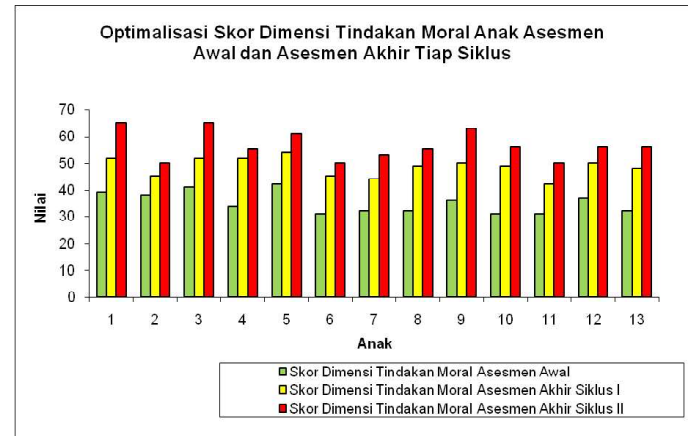

Grafik 4. Optimalisasi Dimensi Perasaan Moral Anak Pada Siklus 1 dan 2

Hasil perhitungan variabel kompetensi moral anak sebelum dan sesudah pelaksanaan Pembelajaran Terpadu Berbasis Moral diperoleh $t^{\text {hitung }}$ sebesar 12.26 sedangkan $t$ tabel untuk df 12 pada $a=0,05$ sebesar 2.18 dan pada $a=0,01$ sebesar 3,055 . Oleh karena $t$ hitung $(12.26)>t$ tabel ( 2.18 atau 3,055 ) baik pada taraf kepercayaan 95\% maupun pada taraf kepercayaan 99\% maka dapat disimpulkan bahwa pembelajaran terpadu berbasis moral dapat mengoptimalkan kompetensi moral anak usia dini.

Uji efektivitas pembelajaran terpadu berbasis moral dilakukan dengan melakukan uji hipotesis data hasil eksprimen sederhana dengan menggunakan uji t-sampel tunggal ( $t$-one sampel) untuk melihat perbedaan nilai rata-rata kompetensi moral anak usia dini sebelum dan sesudah dilakukan perlakuan dengan menggunakan pembelajaran terpadu berbasis moral. Dari hasil uji perbedaan nilai rata-rata asesmen awal dan hasil asesmen akhir diperoleh nilai $t_{\text {hitung }}$ $=24,235$ sedangkan nilai $t_{\text {tabel }}$ pada taraf nyata $a$ 
$=0,05$ dengan df 21 adalah 2.080 dan pada $a=$ 0,01 sebesar 2.831 , oleh karena $t_{\text {hitung }}(24,235)>$ $\mathrm{t}_{\text {tabel }}$ (2.080 atau 2.831) maka dapat disimpulkan bahwa terdapat perbedaan yang signifikan pada nilai rata-rata kompetensi moral anak usia dini sebelum dan sesudah mendapat perlakukan. Dari hasil perhitungan tersebut dapat disimpulkan bahwa $\mathrm{H}_{0}$ ditolak. Hal ini berarti bahwa pembelajaran terpadu berbasis moral dapat mengoptimalkan kompetensi moral anak usia dini.

\section{Pembahasan Hasil Penelitian}

Pembelajaran terpadu berbasis moral terbukti dapat mengoptimalkan kompetensi moral anak usia dini. Pengoptimalan tersebut terjadi karena anak dilibatkan dalam mendiskusikan dan mengambil keputusan terhadap permasalahan moral yang ada di rumah, di kelas dan di lingkungan.

Pada siklus pertama kompetensi moral anak telah mencapai nilai rata-rata dari alat ukur yang digunakan pada penelitian ini. Namun karena ada salah satu dimensi dari kompetensi moral belum mencapai target yaitu tindakan moral, maka dilakukan perbaikan terhadap perencanaan pembelajaran dan dilaksanakan pada siklus kedua. Perbaikan rencana dilakukan dengan memprediksi bahwa penggunaan gambar kurang memberi kesempatan kepada untuk mendapatkan model yang layak ditiru dalam pelaksanaan nilainilai moral yang akan ditanamkan.

Pada siklus kedua kegiatan pembelajaran tetap mencakup optimalisasi pengetahuan, perasaan, dan tindakan moral. Penyempurnaan dilakukan dengan mengganti media gambar dengan gambar visual ditambah dengan permainan-permainan moral. Di samping itu, metode praktek langsung ditambahkan pada siklus kedua sebagai metode optimalisasi tindakan moral anak.

Pelaksanaan hasil revisi tindakan siklus kedua ternyata berhasil mengoptimalkan kompetensi moral anak usia dini. Di samping itu semua dimensi kompetensi moral telah melebihi target penelitian yaitu kategori baik.

Hasil penelitian ini sejalan dengan pendapat Kohlberg bahwa diskusi nilai-nilai moral dapat digunakan untuk mengembangkan dan meningkatkan pemikiran moral anak. Dia juga menyatakan bahwa cara anak maju dari satu tahap ke tahap berikutnya adalah melalui intreraksi dengan anak lain yang berada satu tahap atau dua tahap di atasnya. Guru dapat membantu kemajuan pemikiran moral anak-anak dengan menyediakan diskusi tentang isu-isu keadilan dan perilaku moral lainnya ke dalam pembelajaran, khususnya dalam merespon berbagai peristiwa yang muncul di dalam kelas atau di masyarakat luas.

Di samping itu penggunaan media visual lebih efektif dalam penyediaan model yang dapat ditiru anak sejalan dengan pendapat Bandura (http:// www.ship.edu/ cgboeree/perscontents.html) bahwa hasil pembelajaran hanya dapat dicapai dengan baik jika ada perhatian terhadap model yang akan ditiru. Oleh sebab itu, model-model yang harus ditiru mesti dibuat semenarik mungkin. Misalnya model yang berwarna dan dramatik, atraktif, bergengsi, kompeten akan lebih menarik perhatian. Bagi anak-anak usia dini model-model yang mirip dengan dirinya akan lebih menarik perhatiannya. Di dalam penelitian ini gambargambar dan gambar audio-visual dalam bentuk video singkat yang digunakan menggunakan tokoh anak-anak atau binatang.

Penggunaan model dan dialog juga pernah digagas Norton (dalam Sharma: 2006) dalam mengaplikasikan "pemagangan afektif" (affective apprenticeship) atau "pemagangan dalam pengasuhan" (apprenticeship in caring) dalam pendidikan moral. Dia menjelaskan satu metode "pemagangan dalam pengasuhan" yang mirip dengan langkah-langkah pemagangan kognitif yaitu: modeling menunjukkan proses bagaimana moral akan dicapai, dialog dalam rangka mengeluarkan pemikiran dari guru dan siswa, dan praktik yang mencakup pemagangan perilaku dalam masyarakat. Program pendidikan moral dilakukan secara terpadu dengan menggunakan metode-metode pembelajaran tidak langsung termasuk restrukturisasi sekolah untuk mendukung pengasuhan dan pembelajaran.

Penelitian ini juga sejalan dengan penemuan Nace Toner dan koleganya pada tahun 1978 (dalam Shaffer (2002) bahwa anak usia 6-8 tahun yang dipersuasi dengan model yang mengajarkan moral lebih dapat mengendalikan diri dari godaan daripada anak-anak yang tidak memiliki model 
untuk ditiru. Implikasi dari penemuan ini menurutnya dapat membantu orangtua mengontrol perilaku-perilaku yang tidak diingini pada anak dengan menggunakan model-model yang dapat ditiru anak.

Pada tataran filosofis hasil penelitian ini sejalan gagasan pembelajaran moral dengan menggunakan keteladanan yang telah digagas oleh banyak ahli pendidikan, di antaranya Ki Hajar Dewantara. Ki Hajar Dewantara menyatakan pembelajaran moral harus dilakukan melalui peniruan dan pembiasaan tingkah laku yang baik. Dalam konteks ini Ki Hajar Dewantara mengutip pepatah Belanda "Woorden wekken, woorbeelden trekken" yang artinya: "Kata-kata itu menyadarkan, contoh-contoh teladan itu menarik," Ki Hajar Dewantara mengatakan bahwa salah satu cara yang paling baik dalam menghidupkan adat istiadat pada peserta adalah dengan mengajak mereka melihat seorang pengetua yang dihormati anak melakukan hal tersebut (Ki Hajar Dewantara, 1977:55)

Dalam ajaran Islam keteladanan merupakan hal yang paling penting dalam pendidikan akhlak. Allah telah menjadikan Nabi Muhammad saw sebagai contoh teladan pelaksanaan akhlak yang baik dalam kehidupan sehari-hari. Hal ini difirmankan Allah pada Al-Qur'an surat al-Ahzab ayat 21 yang artinya: "Sesungguhnya telah ada pada (diri) Rasulullah itu suri teladan yang baik bagimu (yaitu) bagi orang yang mengharap (rahmat) Allah dan (kedatangan) hari kiamat dan dia banyak menyebut Allah." Seluruh perilaku Rasulullah baik perkataan, sikap, dan perbuatannya merupakan contoh terbaik bagi umat Islam dalam pelaksanaan akhlak yang mulia menurut ajaran Islam.

\section{Simpulan dan Saran}

\section{Simpulan}

Pertama, Kompetensi moral anak usia dini di lokasi penelitian masih berada pada kategori cukup, tetapi pada dimensi tindakan moral masih berada pada kategori kurang.

Kedua, pelaksanaan Pembelajaran Terpadu Berbasis Moral dalam mengoptimalkan kompetensi moral anak usia dini terdiri dari: kegiatan optimalisasi, media, dan metode: 1) kegiatan optimalisasi kompetensi moral anak mencakup optimalisasi dimensi pengetahuan, perasaan, dan tindakan moral. Ketiga kegiatan optimalisasi dilakukan pada setiap hari pembelajaran dengan skuensi, optimalisasi pengetahuan moral dilakukan pada kegiatan pembukaan; optimalisasi perasaan moral dilakukan pada kegiatan penutup; dan optimalisasi tindakan moral dilakukan pada kegiatan inti, makan, dan istirahat; 2) Media yang digunakan gambar, gambar visual, permainanpermainan moral, dan lembar kerja anak; (3) Metode pembelajaran yang digunakan terdiri dari: mengamati gambar, bermain peran, tanya jawab, penugasan, praktek langsung, dan bimbingan dengan nasehat dan penguatan.

Ketiga, Pembelajaran Terpadu Berbasis Moral dapat mengoptimalkan kompetensi moral anak usia dini hal ini dibuktikan dengan adanya perbedaan yang berarti pada nilai rata-rata kompetensi moral anak sebelum dan sesudah mengikuti pembelajaran terpadu berbasis moral.

\section{Saran}

Berdasarkan hasil dan pembahasan hasil penelitian ini diajukan beberapa saran kepada guru, pengelola pendidikan anak usia dini, peneliti bidang pendidikan anak usia dini, dan pemerintah sebagai berikut:

\section{Guru}

Dalam upaya mengoptimalkan kompetensi moral anak usia dini (5-6 tahun) disarankan agar guru menerapkan pembelajaran terpadu berbasis moral. Di samping guru hendaknya benar-benar kreatif dalam mengembangkan tema dan menyesuaikan dengan nilai-nilai moral yang cocok dengan tema dan perkembangan anak. Guru juga harus kreatif menyediakan media yang menarik bagi anak sebagai stimulasi diskusi tentang nilainilai moral yang diajarkan sekaligus menarik untuk ditiru anak. Guru juga harus merekam perkembangan kompetensi moral anak di samping aspek-aspek perkembangan anak yang lainnya. Tema-tema seperti Kebersihan, Kesehatan, dan Keamanan dapat dijadikan sebagai tema untuk mengembangkan nilai-nilai moral yang berkaitan dengan hidup bersih, jujur, disiplin, bertanggung jawab, dan lain-lain. 


\section{Pengelola Pendidikan Anak Usia Dini}

Hendaknya pengelola pendidikan anak usia dini tidak hanya menyesuaikan misi sekolahnya dengan tuntutan orang tua seperti anak pandai tulis baca dan berhitung sebagai persiapan anak memasuki sekolah dasar. Pihak pengelola pendidikan anak usia dini juga hendaknya menetapkan misi sekolahnya sebagai sekolah yang mempersiapkan anak-anak yang memiliki kompetensi moral sesuai dengan usianya. Di samping itu pihak pengelola sekolah seyogyanya memfasilitasi guru dengan menyediakan peralatan dan media yang diperlukan dalam pembelajaran moral sehingga guru terbantu dan bersemangat dalam menerapkan nilai-nilai moral sebagai basis pembelajaran terpadu yang dilaksanakan di sekolah.

\section{Peneliti}

Para peneliti yang akan melakukan penelitian pada bidang kajian yang sama hendaknya memperhatikan keterbatasan-keterbatasan yang ada dalam penelitian ini agar hasil yang diperoleh lebih sempurna, seperti: 1) melibatkan peran serta orang tua dalam upaya pengembangan dan pembiasaan moral anak di sekolah, 2) melaksanakan penelitian dalam subjek penelitian yang lebih luas dan lebih beragam dalam bentuk penelitian eksprimen, 3) menggunakan metode dan strategi yang berbeda dalam upaya optimalisasi kompetensi moral anak usia dini, dan 4) mengikutsertakan berbagai faktor yang mempengaruhi optimalisasi kompetensi moral anak usia dini dalam pembelajaran.

\section{Pemerintah}

Pemerintah khususnya Direktorat Pendidikan Anak Usia Dini dapat menyusun sebuah model pembelajaran yang sarat dengan pengembangan nilai-nilai moral pada anak sebagai salah satu implementasi dari upaya pencapaian tujuan pendidikan nasional. Nilai-nilai moral dapat diimplementasikan pada kegiatan pembukaan, inti dan penutup pada model Sentra dan Saat Lingkaran (Beyond Centres dan Circle Times) yang saat ini sedang digalakkan Direktorat Pendidikan Anak Usia Dini.

\section{Pustaka Acuan}

Asri C. Budiningsih. 2004. Pembelajaran Moral: Berpijak Pada Karakteristik Siswa dan Budayanya, Jakarta: Rineka Cipta.

Baihaqi, H.R. Kitab Sunanul Kubra, Mesir: Dar al-Muassasah, (tanpa tahun)

Berk, Laura E. 2006. Child Development, Boston: Pearson Education.

Bernt, Thomas J. 1997. Child Development, Madison: Brown \& Bencmark.

Catalano, Richard F., M. Lisa Berglund, Jeanne S. Conczak, dan J. David Hawkins. 1998. Positive Development in the United Stated: Research Finding on Evalution of Positive Youth Development Programs, Washington: Social Development Research Group University Washington School of Social Work.

Departemen Agama. 1986. Al-Qur'an dan Terjemahannya, Jakarta: Departemen Agama.

Deighton, Lee C. (Ed.). 1967. The Encyclopedia of Education, London: The Macmillan Company and The Free Press.

Durkheim, Emile. 1990. Pendidikan Moral: Suatu Studi dan Aplikasi Sosiologi Pendidikan, Terjemahan Lukas Ginting Jakarta: Erlangga,

Haris Alan, 1976. Teaching Morality and Religion, London: Geoge Allen \& Unwin Ltd., Henderson, Stella Van Petten, 1964. Introduction to Philosophy of Education, Chicago: The University of Chicago Press.

Kanfer, Ruth dan Phillip L. Ackerman. 2005. Work Competence: A Person-Oriented Perspective, dalam Andrew J. Elliot dan Carol S. Dweck Ed. Handbook of the Competence and Motivation New York: The Guilford Press. 
Kemmis, Stephen dan Robin McTaggart. 1997. The Action Planner Victoria: Deakin University.

Kohlberg, Lawrence, 1976. Tahap-tahap Perkembangan Moral, Terj. Jhon de Santo dan Agus Cremers Yogyakarta: Kanasius.

Ki Hajar Dewantara. 1977. Bagian Pertama Pendidikan, Yogyakarya: Majelis Luhur Persatuan Taman Siswa.

Lickona, Thomas. 1991. Educating for Character: How Our Schools Can Teach Respect and Responsibility New York: Bantam.

Lind, George, Moral Competence and Education in a Democratic Society Discussion www.unikonstanz.de/ag-.moral

Martini Jamaris, "Kiat-Kiat Pengembangan Potensi Anak Usia Dini: Penerapan Multiple Intelligences dalam Kurikulum Berbasis Kompetensi dan Aplikasinya Melalui Pembelajaran Terpadu" dalam Jurnal Pendidikan Usia Dini Vol.3 No. 2 Tahun 2005

Martin, Barbara L. dan Charles M. Reigeluth, 1999. "Affetive Education and the Affective Domain: Implications for Instructional-Design Theories and Models" dalam Reigeluth, Charles M. Ed., Instructional-Design Theories and Models: A New Paradigm of Instructional Theory London: Lawrence Erlbaum Associates Publisher.

Mills, Geoffery E. 2003. Action Research A Guide for The Teacher Researcher Columbia: Merril Printice Hall.

Ornstein, Allan C. dan Daniel U. Levina. 1985. An Introduction to The Foundation of Education Boston: Houghton Mifflin Company.

Piaget, Jean dan Bärbel Inhelder. 1969. The Psychology of The Child London: Routledge \& Kegan Paul.

Ratna Megawangi, 2007. Pendidikan Karakter: Solusi Tepat untuk Membangun Bangsa Jakarta: Viscom Pratama.

Rakhimahwati, "Penanaman Sikap Moral Pada Anak Usia Dini." Bulletin Pembelajaran Nomor 4 Tahun 25, 2002

Santrock, Jhon. 1996. Life-Span Development Boston: Pearson Education

Schultheiss, Oliver C. dan Joachim C. Brunstein. 2005. "An Implicit Motive Perspective on Competence" dalam Andrew J. Elliot dan Carol S. Dweck Ed. Handbook of the Competence and Motivation New York: The Guilford Press.

Shaffer, David R. 2002. Developmental Psychology Childhood and Adolescence Australia: Thomson Learning.

Sharma, S.R. Ed. 2006. Curriculum for Moral Education New Delhi: Cosmo Publications.

Sjarkawi. 2006. Pembentukan Kepribadian Anak: Peran Moral, Intelektual, Emosional, dan Sosial Sebagai Wujud Integritas Membangun Jati Diri Jakarta: Bumi Aksara.

Tempo 13 Juni 2006

Undang-Undang Repbulik Indonesia. 2003. No. 20 Tahun 2003 Tentang Sistem Pendidikan Nasional Jakarta: Eka Jaya.

Weiner, Bernand. 2005"Motivation from Attribution Perspective and Social Psychology of Perceive Competence" dalam Andrew J. Elliot dan Carol S. Dweck Ed. Handbook of the Competence and Motivation New York: The Guilford Press.

Winston, Kenneth. 2002. Moral Competence in the Practice of Democratic Governance Harvard University: KSG Faculty Research Working Paper Series.

http://www.ypha.or.id

http://www.antara.com

www.uni-konstanz.de/ag.moral

http://www.ship. edu/ cgboeree/perscontents.html 